\title{
Long Term Bisphosphonate Use in Osteoporotic Patients; A Step Forward, Two Steps Back
}

\author{
Pooneh Salari ${ }^{1}$, Mohammad Abdollahi ${ }^{2}$ \\ ${ }^{1}$ Medical Ethics and History of Medicine Research Center, Tehran University of Medical Sciences, Tehran, Iran. \\ ${ }^{2}$ Faculty of Pharmacy; and Pharmaceutical Sciences Research Center; and Endocrinology \& Metabolism Research Center, \\ Tehran University of Medical Sciences, Tehran, Iran.
}

Received, January 3, 2012; Revised, March 2, 2012; Accepted, April 25, 2012; Published, April 25, 2012.

\begin{abstract}
Purpose. Bisphosphonates are the main class of drugs widely used in prevention and treatment of osteoporosis. Along with the beneficial effects, recent studies point to the harms of long-term treatment with bisphosphonates. Methods. The most relevant articles reporting serious adverse effects of bisphosphonates were selected and reviewed with the aim of assessing the risk-benefit of bisphosphonates. We searched PubMed, Web of Science, and Scopus using keywords bisphosphonates, risk of fracture, atrial fibrillation, osteonecrosis jaw, esophageal cancer, and adverse effects with no time limitation. We limited our s research to English articles. Results. Our review shows that bisphosphonates reduce vertebral fractures in short term use while in long-term can cause osteonecrosis jaw, esophageal cancer, atrial fibrillation, and increase the risk of atypical fractures and probably adynamic bone disease. There is no consensus on the time limitation of bisphosphonate usage or its long term adverse effects. Thus, more studies on long-term side effects of bisphosphonates are highly recommended. In addition, new approaches for prevention and treatment of osteoporosis seem necessary. Conclusion. Prescribers should act cautionary and consider full assessment of risk-benefit and the duration of treatment.
\end{abstract}

This article is open to POST-PUBLICATION REVIEW. Registered readers (see "For Readers") may comment by clicking on ABSTRACT on the issue's contents page.

\section{INTRODUCTION}

Osteoporosis is considered as one of the chronic senile diseases with complex complications and comorbidities. One of its major complications is the bone fracture which is associated with high cost and debilitates. Principally its management consists of prevention strategies and pharmacotherapy. Investigation are focused on a better understanding of the pathogenesis of osteoporosis, bone metabolism and the role of inflammation, special cells and inflammatory pathways, oxidative stress as well as the link between chronic senile diseases may help finding a solution [1-9].

In the therapeutic front, treatment modalities of osteoporosis include a wide range of medications with their efficacy and side effects being major concerns. Previously we have reported that various classes of medications for osteoporosis suggest new hopeful therapeutic approaches that are potentially associated with less harm [10]. Treatment of osteoporosis by bisphosphonates reduces the rate of fracture as the primary endpoint and increases bone density and reduces bone metabolism as the secondary endpoint. Hence, despite the emergence of new treatment approaches, bisphosphonates remain the cornerstone of prevention and treatment in the field albeit the outcomes of recent studies are confusing and disappointing. The efficacy and short-term safety profile of bisphosphonates have been proved in several studies $[10,11,12]$, however, there are concerns about their long-term use. Furthermore bisphosphonates can be released into blood circulation years after discontinuation raising the possibility of long term adverse effects and in this regards, bisphosphonates have a maintenance effect on bone metabolism possibly depending on the dose and duration of treatment $[13,14]$. We, therefore, aimed at providing the pros and cons of bisphosphonates use and discuss the best approach in the application of bisphosphonates especially their long term use.

Corresponding Author: Pooneh Salari, Medical Ethics and History of Medicine Research Center, Tehran University of Medical Sciences, Tehran, Iran; poonehsalari@gmail.com 


\section{Mechanism of action}

Preferentially bisphosphonates are absorbed into the bone tissues and selectively inhibit bone resorption mediated by osteoclasts. Recently it has been suggested that bisphosphonates decrease osteocytes apoptosis [15]. Bisphosphonates decrease bone remodeling which can be measured by bone biomarkers. Initiating bisphosphonates reduces bone resorption biomarkers in the first 3 months and bone formation markers reaches its lowest level in 6 months [15].

Although the most favorable effects of biphosphonates on bone are increased bone mineral density (BMD) and reduced fracture risk which seem to be aquired after long-term use, the results of long-term studies raised major concerns about their efficacy and safety not only on bone but also on the gastrointestinal (GI) and cardiovascular systems. The side effects include osteomalacia, GI disorders, musculoskeletal pain, hypocalcemia and osteonecrosis jaw (ONJ) that are discussed later in details (Figure 1).

\section{Available Bisphosphonates}

Structurally bisphosphonates are divided into two groups: early without nitrogen atom including etidronate, clodronate and newer bisphosphonates containing nitrogen atom including alendronate, pamidronate, ibandronate, risedronate and zoledronic acid [15]. Early bisphosphonates have narrow therapeutic window and the difference between their therapeutic and toxic dose is small while the emerging nitrogen-containing bisphosphonates (NCBPs) have extended the therapeutic window. NCBPs are potentially more active on osteoclasts that the former group [15].

\section{METHODS}

\section{Evidence Acquisition}

The most relevant articles reporting the serious adverse effects of bisphosphonates were selected and reviewed for the risk-benefit assessment of bisphosphonates. We searched PubMed, Web of Science, and Scopus using keywords bisphosphonates, risk of fracture, atrial fibrillation, osteonecrosis jaw, esophageal cancer, and adverse effects with no time limitation. We limited our results to articles published in English.

Some key studies on the effects of bisphosphonates are presented in Table 1 .

Table 1. Summary data of long-term studies conducted on bisphosphonates

\begin{tabular}{|c|c|c|c|c|}
\hline Study & Subjects & Duration & Design & Conclusion \\
\hline Pols et al. (53) & $\begin{array}{l}1908 \\
\text { PMOW }\end{array}$ & $1 \mathrm{yr}$ & $\begin{array}{l}\text { Randomized double- } \\
\text { blind }\end{array}$ & Alendronate $\rightarrow \uparrow \mathrm{BMD}^{*}, \downarrow \mathrm{NVF}^{*}$ \\
\hline Bone et al. (85) & $247 \mathrm{~W}$ & $10 \mathrm{yrs}$ & $\begin{array}{l}\text { Randomized double- } \\
\text { blind }\end{array}$ & $\begin{array}{l}\text { BPs discontinuation after } 10 \text { yrs } \rightarrow \downarrow \text { BMD, } \\
\text { but does not mean loss of benefit }\end{array}$ \\
\hline Mellström et al. (84) & 164 & $7 \mathrm{yrs}$ & $\begin{array}{l}\text { Randomized double- } \\
\text { blind }\end{array}$ & $\begin{array}{l}\text { Risedronate } \rightarrow \uparrow \mathrm{BMD}^{*}, \downarrow \text { bone turnover*, } \\
\text { no indication of loss of anti-fracture } \\
\text { efficacy }\end{array}$ \\
\hline Odvina et al. (61) & $9 \mathrm{P}$ & $2 \mathrm{yrs}$ & Case report & $\begin{array}{l}\mathrm{ALN} \rightarrow \text { delayed fracture healing, severe } \\
\text { suppression of bone metabolism }\end{array}$ \\
\hline Felsenberg et al. (83) & $\begin{array}{l}1964 \\
\text { PMOW }\end{array}$ & $3 \mathrm{yrs}$ & $\begin{array}{l}\text { Retrospective analysis } \\
\text { of BONE study }\end{array}$ & Ibandronate $\rightarrow \downarrow \mathrm{VF}^{*}$ \\
\hline Black et al. (86) & 1099 PMW & $10 \mathrm{yrs}$ & $\begin{array}{l}\text { Randomized double- } \\
\text { blind }\end{array}$ & $\begin{array}{l}\text { BPs discontinuation after } 5 \mathrm{yrs} \rightarrow \downarrow \mathrm{BMD}^{*} \text {, } \\
\uparrow \mathrm{BBMs}^{*}, \uparrow \mathrm{VF}\end{array}$ \\
\hline Goh et al. (63) & 13 & Long-term & Retrospective & $\begin{array}{l}\text { ALN } \rightarrow \text { Prolonged suppression of bone } \\
\text { remodeling \& new form of femur fracture }\end{array}$ \\
\hline Stepan et al. (79) & 66 PMOW & Long-term & Retrospective & $\begin{array}{l}\text { The association of lower femoral neck } \\
\text { BMD \& increased age with microdamage } \\
\text { accumulation in ALN users }\end{array}$ \\
\hline
\end{tabular}


Table 1, Continued...

\begin{tabular}{llll} 
Study & Subjects & Duration & Design \\
\hline McCloskey et al. (43) & 5579 PMW & 3 yrs & $\begin{array}{l}\text { Randomized double- } \\
\text { blind }\end{array}$ \\
Chapurlat et al. (80) & 50 PMOW & $3 y r s$ & $\begin{array}{l}\text { Cross-sectional } \\
\text { Sy }\end{array}$
\end{tabular}

\section{Conclusions}

Kwek et al. (64)

Visekruna et al. (67)

Lenart et al . (66)

Neviaser et al. (65)

Lee (69)

Abrahamsen et al.

(59)

Ing-Lorenzini et al. 8

(72)

Lenart et al. (75)

Capeci et al. (73)

Black et al. (60)

Schwartz et al. (87)

15 PMOW

$70 \mathrm{OP}$

$1 \mathrm{P}$

$27505 \mathrm{P}$

8 P

41

PMOW(R)

7

PMOW(R)

$14195 \mathrm{~W}$

Occhicone et al. (120)

Odvina et al (74)

Isaacs et al. (76)

Girgis et al. (77)

Venkatanarasimha et

al. (68)

Park-Wyllie et al.

(71)

Harrington et al (56)

Hwang et al. (121)

Iba et al. (112)

Kim et al. (70)

Vestergaard et al. (95)

$100 \mathrm{P}(\mathrm{R})$

$152 \mathrm{P}(\mathrm{FR})$
$17 \mathrm{P}$

$3 \mathrm{P}$

1099 PMW

$\begin{array}{ll}4.8 \text { yrs } & \text { Retrospective } \\ \text { Long-term } & \text { Case report }\end{array}$

$5.4 \mathrm{yrs}$

2.5-7 yrs

Retrospective

Retrospective

8 yrs Case report

Not Cohort \& cross

specified sectional

Long term Case report

Long-term Retrospective casecontrol study

8.6 yrs Retrospective

Not

specified

Analyzed the results of

FIT, FLEX, HORIZON, \& PFT

$10 \mathrm{yrs}$

101 PMOW Not specified

13 OP 3-11 yrs

Not

specified

Post hoc analysis on FLEX study data

Prospective

Retrospective

Retrospective casecontrol study

Retrospective

Case review

10439 OW 7 yrs Cohort

$\begin{array}{lll}\begin{array}{ll}1172 \\ \text { PMOW }\end{array} & 3 \text { yrs } & \begin{array}{l}\text { Randomized double- } \\ \text { blind } \\ \text { 323 OW }\end{array} \\ & 3 \text { yrs } & \begin{array}{l}\text { Pos hoc analysis of } \\ \text { HORIZON }\end{array} \\ \text { 13 OP } & 42 \text { months } & \begin{array}{l}\text { Retrospective } \\ \text { Retrospective }\end{array}\end{array}$

$414245 \mathrm{P} \quad 10 \mathrm{yrs} \quad$ Cohort
Clodronate $\rightarrow \downarrow$ clinical fracture* except for hip fracture

Low microcrack in iliac bone; No association between microcrack frequency and duration of BP therapy,

$\mathrm{ALN} \rightarrow$ insufficiency stress fracture ALN combined with anti-remodeling therapy $\rightarrow$ atypical skeletal fragility because of SSBT*

$\mathrm{ALN} \rightarrow$ atypical low-energy fractures

$\mathrm{ALN} \rightarrow$ low energy fractures of femoral shaft

ALN for $8 \mathrm{yrs} \rightarrow$ atypical FF

No relationship between BPs and increased FR; Similar ratio of fracture in alendronate and control groups, $\mathrm{ALN} \rightarrow \uparrow \mathrm{FR}$

Possible negative interaction between BPs, PPIs \& corticosteroids $\rightarrow \uparrow \mathrm{FR}$

The association of higher FR with long term BP

Considering discontinuation of ALN

therapy after presenting fracture

No significant increase in FR is associated with BP use

$\mathrm{ALN} \rightarrow \downarrow N V F$ in women without prevalent $\mathrm{VF}$, but not in women with T Score $>-2$ The incidence of new SF was the same in treated and not treated patients

Long term $\mathrm{BP} \rightarrow \uparrow$ risk of atypical bone fracture

Long term $\mathrm{BP} \rightarrow \uparrow$ risk of insufficiency fractures

Association between atypical femur fracture and BPs

$\mathrm{ALN} \rightarrow$ atypical low-energy fractures

Treatment with BPs $\geq 5 \mathrm{yrs} \rightarrow \uparrow$ risk of atypical fractures (the absolute risk is low); $\downarrow$ risk of typical fractures

Significant reduction of the incidence of NVF as early as 6 months by risedronate $\mathrm{ZA} \rightarrow \downarrow \mathrm{VF}^{*}, \uparrow \mathrm{BMD}^{*}$

Treatment did not cause atypical fracture Prevalent VF is a strong risk factor for new VF independent of BMD.

$\mathrm{BPs} \rightarrow \uparrow$ risk of typical and atypical fractures, but the role of confounding should be considered

$\mathrm{PMOW}=$ postmenopausal osteoporotic women; $\mathrm{PMW}=$ postmenopausal women; $\mathrm{OP}=$ osteoporotic patients; $\mathrm{OW}=$ osteoporotic women; $\mathrm{W}=$ women; $\mathrm{P}=$ patients; $(\mathrm{R})=$ presented with fracture; $\mathrm{BMD}=$ bone mineral density, $\mathrm{NVF}=$ nonvertebral fracture; VF- vertebral fracture; $\mathrm{FF}=$ femoral fracture; $\mathrm{FR}=$ fracture risk; $\mathrm{SF}=$ subtrochanteric fracture; $\mathrm{SSBT}=$ severely suppressed bone turnover; $\mathrm{BBMs}=$ bone biomarkers; $\mathrm{BPs}=$ bisphosphonates; $\mathrm{ALN}=$ alendronate; $\mathrm{ZA}=\mathrm{zoledronic}$ acid; PPIs= proton pump inhibitors . 


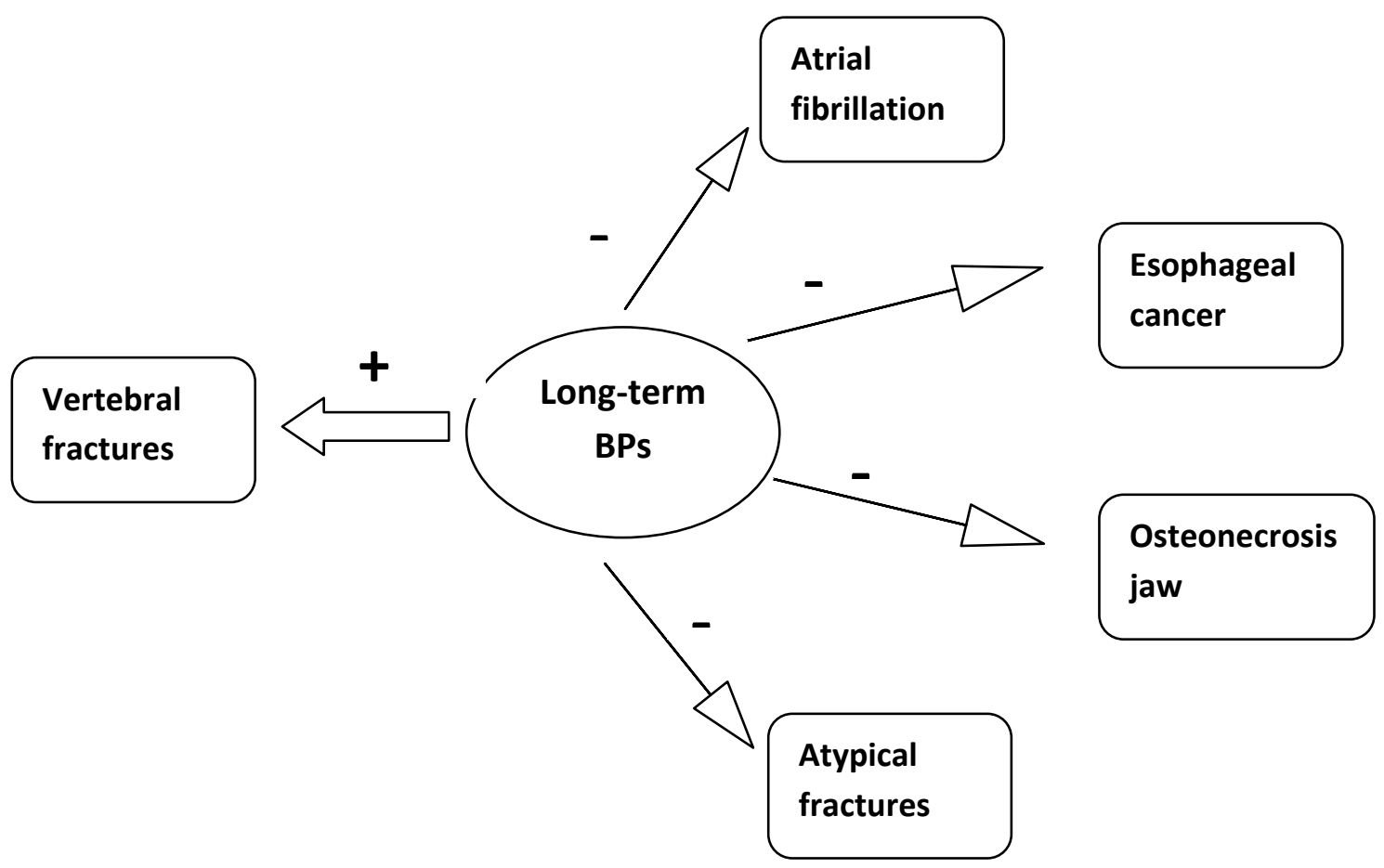

Figure 1. The overall health effects of bisphosphonates $-\mathrm{BPs}=$ bisphosphonates

\section{Reported Side effect}

\section{Upper GI}

One of the most common side effects of this class of drugs is GI disorders including dyspepsia, abdominal pain, nausea, and gastritis. Based on the case reports from United States, Europe and Japan, the U.S. Food and Drug Administration (FDA) in 2009 warned the public of the association of esophageal cancer with oral bisphosphonates [16]. The warning was based on 23 esophaseal cancer cases associated with alendronate usage for median time of 2.1 year [15].

The association of esophageal cancer with risedronate, ibandronate and etidronate were also reported in Europe and Japan after median time of 1.3 years of usage [15]. The relationship between esophageal cancer and oral bisphosphonates can be explained by the esophagitis - esophageal inflammation caused by bisphosphonates followed by squamous cell carcinoma and adenocarcinoma of the esophagus. Solomon et al. could not confirm this association in a U.S. Medicare health plan database [17], and Abrahamsen et al. even reported a reduced risk of esophageal cancer by oral bisphosphonates compared with control group for a mean of 2.8 years [18].

Accordingly another case report mentioned no association between oral bisphosphonates and esophageal adenocarcinoma in Barretts esophagus [19]. In contrast Green et al. [20] observed a significant increase in risk of esophageal cancer by oral bisphosphonates in a large case-control study within a UK cohort. They reported more significant risk from $1 / 1000$ to $2 / 1000$ in $60-79$ year old range with 10 or more bisphosphonate prescriptions / patient in over 3 years as compared with one to nine prescriptions. This was for all type of bisphosphonates and for all ages regardless of the BMI, sex, smoking or alcohol use. In contrast, they find no change in the risk of cancer of stomach and colorectum by oral bisphosphonates [20]. Interestingly, when Cardwell et al. analyzed the information extracted from the Green et al study in nearly twice as long as Green et al period of time, they could not confirm a significant association between risk of esophageal or gastric cancer and oral bisphosphonates [21]. According to the new announcement of FDA, there have been conflicting findings in this issue and FDA is still reviewing data [22]. 


\section{Osteonecrosis jaw}

Osteonecrosis of the jaw (ONJ) which was firstly reported in 2003 is one of the side effects of NCBPs with an incidence of approximately $1 / 10000$ to $1 / 100000$ patient treatment years [23,24].

Firstly, the problem is presented as a nonhealing extraction socket or exposed jawbone associated with swelling and purulent discharge refractory to antibiotic treatment [25]. According to the American Society for Bone and Mineral Research, ONJ is described as an area of a nonhealing exposed bone in the maxillofacial region in a patient who is/was exposed to a bisphosphonate and did not undergo radiation to the craniofacial region [23].

The pathogenesis behind this side effect is proposed as suppression of bone turnover and vascular insufficiency caused by bisphosphonates [26]. Its incidence is correlated with cumulative dose and length of usage, potency of the bisphosphonate, route of administration, oral hygiene as well as the age and race of the patient, cancer diagnosis and underlying diseases $[25,27]$. In 2003 Bamias et al assessed 252 patients who received bisphosphonates for 6 years prospectively. They confirmed the association of bisphosphonate usage and ONJ and considered duration of exposure as an important risk factor for ONJ. They reported a higher cumulative hazard with zoledronic acid compared with pamidronate alone or pamidronate and zoledronic acid sequentially [28]. The risk of ONJ by oral bisphosphonates seems to be lower than IV route of administration [29]. Formerly cancer was considered as a risk factor for ONJ but a prospective phase III trial in women with stage II/III breast cancer ruled out the role of cancer as a risk factor for ONJ [30]. However, cancer patients with bone metastasis using intravenous NCBPs are at the highest risk of developing ONJ [31]. King et al reviewed 44 case reports and determined more frequent ONJ in intravenous bisphosphonate users (453 patients [94.2\%] out of 481) than in patients receiving oral bisphosphonates (28 patients [5.8\%]) [32]. Some investigators suggest the development of necrosis even after bisphosphonate cessation [33]. The result of a case review study revealed the higher risk of ONJ to be within 2 years of bisphosphonate use which increased fourfold after 2 years [34].

\section{Risk of fracture}

Vertebral fractures are the most reliable indicators of reduced bone density, hence, a reduction of fracture risk is often the first endpoint in osteoporosis studies. The FDA has approved all bisphosphonates as efficient drugs in reducing rates of vertebral fractures but there is no consistency on reducing hip fractures. However, investigations on the effect of bisphosphonates on non-vertebral fractures have also been carried out.

There are several potential trials reporting reduction in new vertebral, non vertebral, hip and wrist fractures, by alendronate, risedronate, ibandronate, clodronate and zoledronic acid [3551]. Meta-analyses on alendronate have shown 0significant efficacy in reducing vertebral, non vertebral, hip and wrist fractures as secondary prevention with no significant results for primary prevention except for vertebral fractures $[52,53]$. However, studies on etidronate and residronate demonstrated their effectiveness only in secondary prevention of vertebral fractures with no significant effect on primary prevention and non vertebral fractures [54-56].

Despite the overwhelming data to support the effectiveness of bisphosphonates in reducing risk of fracture, there are some case reports suggestive of increased risk of atypical femoral fracture associated with long term use of these drugs $[57,58]$. This notion, however, is not generally agreed upon $[59,60]$. Part of the problem is that the optimal duration of bisphosphonate therapy to achieve beneficial effects, hence, the duration of monitoring the side effects are still undecided. Some have reported a loss of efficacy after 2 years [61] while some others did not notice antifracture activity following 10 years of bisphosphonate treatment [62]. Recent evidences are indicating suppression of the bone turnover and increased risk of bone fragility after long term bisphosphonate therapy [57]. The delayed recovery from fracture and evidences of severe suppression of bone metabolism were, first, observed by Odvina [61]. Between 2006 and 2007 the first case report indicating atypical insufficiency fractures after long term exposure to bisphosphonates was published [63]. The other case reports, indicated subtrochantric, atypical proximal femoral, and femoral fractures with or without clinical and radiographic features by insisting on the long-term exposure to bisphosphonates [64-67]. In a brief 
case report, femoral fractures after long-term bisphosphonate administration in patients with inflammatory diseases such as rheumatoid arthritis, Crohn's disease, have appeared [68]. In addition, Venkatanarasimha et al provided evidence of a link between bisphosphonate usage and subtrochanteric fractures in a review article[69]. Lee et al reported atypical femoral fractures in a patient after 8 years of bisphosphonate therapy with their X-ray showing typical horizontal fracture line in both femurs. The histopathology examination showed lack of osteoblasts and osteoclasts in the tissue extracted from fracture ends and osteopenia over the femoral neck confirmed by bone densitometry [70].

Kim et al conducted a propensity score matched cohort study to measure incidence rate and risk of subtrochanteric or diaphyseal femur fractures in bisphosphonate users in comparison to raloxifene or calcitonin users. Their results showed that the incidence rate of subtrochanteric or diaphyseal femur fractures is rare and no evidence of the increased incidence with bisphosphonates was found while they did not deny the possible impact of long-term bisphosphonates [71].

A population-based study confirmed the association between increased risk of subtrochanteric or femoral shaft fractures and more than 5 years bisphosphonate usage, however they reported the risk as low [72]. Other case reports stated the possible association between long-term bisphosphonate therapy and other drug classes affecting bone metabolism that may yield increased risk [73]. However, similar fractures were seen after long-term use of bisphosphonate without other medications affecting bone metabolism [74].

Noteworthy is the observation of new fractures after both the long-term bisphosphonate (mostly alendronate) alone and also in combination with other medications with the potential to affect bone metabolism.[75,76]. The results of a retrospective case-control study performed by Lenart et al showed significant unique X-ray pattern after bisphosphonate use [76] which is in agreement with the findings of the study of Isaacs et al [77]. The opposing reports that argue against the increased risk include an analysis of a cross-sectional study on Danish patients showed similar ratio of fractures between alendronate-treated patients and untreated controls and the investigators observed that increased use of alendronate in patients with high risk of fracture, augments the risk of fractures in alendronate users [59]. Girgis et al supported the association between atypical fracture and bisphosphonates by reviewing 152 femoral fractures in women [78]. In a retrospective analysis, Schilcher et al reported smaller risk of fractures due to bisphosphonate usage in comparison with osteoporosis alone [79]. Stepan et al found microcracks in bone biopsy after long-term alendronate therapy [80], however after about 6.5 years of alendronate administration, Chapurlat et al could not find those remarks [81]. Black et al analyzed the results of three bisphosphonate trials, the Health Outcomes and Reduced Incidence with Zoledronic Acid Once Yearly (HORIZON), Pivotal Fracture Trial (PFT), the Fracture Intervention Trial (FIT) and the FIT Long-Term Extension (FLEX) trial. They analyzed the records of more than 14000 patients for approximately 10 years. They indicated that the correlation between risk of atypical femoral fractures and bisphosphonate therapy is extremely low [60]. Rizzoli et al thoroughly reviewed the subject and concluded that more than a 5 year treatment doubles the risk of subtrochantric femoral fractures, however, they suggested the risk-benefit ratio to be favorable [82]. In a recent survey, Colón-Emeric et al determined the impact of zoledronic acid on the modification of risk of fracture after low-trauma hip fracture in a post-hoc analysis. They randomized 2127 patients and followed them for 90 days after hip surgery to receive zoledronic acid or placebo. They concluded that zoledronic acid could not lessen the influence of risk factors including age, sex, BMI and fall on the subsequent fractures [83].

The increased risk of fracture secondary to the use of bisphosphonates has not been noticed by Felsenberg et al, who retrospectively analyzed the results of Ibandronate Osteoporosis Vertebral Fracture (BONE) trial noticed a dominant effect for ibandronate on reducing the risk of new vertebral fractures in the more severe forms of vertebral fractures at years 1, 2 and 3 [84]. Mellstrom et al who evaluated the effects of 7 years risedronate therapy observed maintenance of increase in BMD, decrease in bone biomarkers and no indication of loss of anti-fracture efficacy [85]. The results were confirmed by others following 10 years of alendronate therapy [62]. Black et al showed that discontinuation of alendronate after 5 years does not significantly increase fracture risk and further, continuing alendronate treatment beyond 5 years may benefit women at higher risk of vertebral fractures [86]. Schwartz et al differentiated women 
with femoral $\mathrm{T}$ score of -2.5 or less after 5 years alendronate therapy and those with higher $\mathrm{T}$ scores and resulted that extending therapy for 10 years reduces non-vertebral fractures in the first group ( $T$ score $\leq-2.5)$ [87].

Other than duration of treatment the effect of the size of bisphosphonates dose has recently attracted attention. Makras et al studied the effect of different doses of intravenous pamidronate on the incidence of fracture in 92 postmenopausal osteoporotic women. They observed that every prevalent vertebral fracture increases the risk of a new vertebral fracture by $32 \%$ in comparison with $25 \%$ for patients with non-vertebral fractures who received lower dose of pamidronate. The patients who followed intravenous pamidronate by oral pamidronate had higher incidence of nonvertebral fractures [88].

\section{Atrial fibrillation}

Thus far, a few trials have raised awareness toward association of serious cardiac arrhythmias especially atrial fibrillation (AF) after bisphosphonate therapy $[89,90]$. Therefore the US FDA is reviewing this potential cardiac adverse effects of bisphosphonates [91].

Black et al [38] studied annual zoledronic acid injection in postmenopausal osteoporotic women and demonstrated significant risk of serious AF in the treatment group versus placebo but they could not find difference in the rate of stroke between two groups. However, a subsequent post-hoc analysis of the data using a randomized clinical fashion on alendronate in 6459 postmenopausal women for 4 years showed no difference in total AF events between treatment and placebo groups. Nevertheless, 47 cases of serious AF were reported in the treatment group [89]. The re-analysis of data from 3 clinical trials on bisphosphonates could not confirm the association between bisphosphonates usage and risk of AF [90].

An observational study of Heckbert et al [92] indicated a strong association between sustained AF rather than transient $\mathrm{AF}$ and alendronate which was supported by analysis of the National Prescription Database from 1995 to 2005 [93]. In contrast no correlation between bisphosphonates and risk of $\mathrm{AF}$ was demonstrated in six observational studies [9498].

Loke et al and Kim et al in two meta-analysis indicated that heterogeneity of the existing evidences and paucity of some information limit our understanding of the association between serious AF and bisphosphonates [99,100]. Further meta-analysis by Mak et al could not show higher risk of AF with bisphosphonates while they suggested clinicians to consider the probability [101]. In contrast Bhuriya et al included 26126 postmenopausal women in their meta-analysis and indicated a significant increase in risk of serious $\mathrm{AF}$ after bisphosphonate use [102].

Contrary to the above mentioned studies frequent zoledronic acid doses in oncology patients did not increase risk of AF $[103,104]$. Lyles et al evaluated the risk of AF in 1065 patients receiving zoledronic acid in HORIZON Recurrent Fracture trial and could not find significant difference between those patients with patients receiving placebo [105].

\section{DISCUSSION}

With regards to the therapeutic outcome of bisphosphonate therapy, there seems to be a significant difference between short and long term regimens. The function of these drugs appears to be biphasic. There exists an overwhelming body of literature supporting the short term beneficial effects of bisphosphonates. However, the efficacy and safety of these drugs during the second phase, i.e., long term effect, is uncertain.

The issue becomes even more complicated when one realizes that there is no conventional agreement on the definition of the short and long term bisphosphonate regimens. The plausible mechanism for long-term effects of bisphosphonates on the bone appears to stem from their penetration into the bone tissue and their subsequent influence in affecting microdamage repair mechanisms with increases in bone fragility as the outcome. This may also cause degenerative bone disease [106,107]. It is important to emphasize that reported human bone biopsies taken 6 months to 10 years after drug administration do not support the idea of suppression of bone remodeling $[108,109]$. Animal data on this subject has been controversial [110,111].

Other than the long term effects of bisphosphonates on bone, their adverse effects on the gastrointestinal tract and the cardiovascular system must be considered. Similarly, although controversial, consideration must be given to the risk of esophageal cancer caused by bisphosphonate 
particularly in patients in premalignant conditions. Another points the begs attention is the musculoskeletal pain in some patients under bisphosphonate therapy that may involve bone, joint, or musculoskeletal tissue at any time after starting drug therapy that may not stop for some time after discontinuation of the drug [15].

Overall, the side effects appear to be influenced by factors such as the type of the drug, duration and route of administration, old age, fracture prevalence and combined drug therapy. An additional factor to consider is the dosing frequency and the size of the dose. Shiraki et al who evaluated the possible association between the metabolic effects of bisphosphonates and fractures, identified old age, higher number of prevalent fractures, higher osteocalcin levels, and lower lumbar BMD as risk factors for incident fractures despite of bisphosphonate use [112]. For bisphosphonates, the side effects ascribed to daily doses, the long-term treatment nature of the therapy and the prolong after-dose effect, has prompted the sponsors to develop and market once weekly, once monthly and once yearly drug regimens. Whether, these treatment regimens will yield differences in the long term safety and efficacy of the class of the drugs has remained unknown.

It is worthy to note that most studies reporting long-term exposure to bisphosphonates have focused on alendronate with only a few case reports on ibandronate, risedronate and zoledronic acid $[65,68,75,113]$. This is expected since the latter was the first to be marketed.

In the recent decades promising advancements have been made in identifying bone biomarkers as surrogates of bone metabolism. Iba et al have shown that the N-telopeptide of type I collagen levels returns to normal in 13 osteoporotic patients who were under therapy with bisphosphonates who had reduced level of the biomarker [114]. In another recent study, the investigators demonstrated that age, prevalent fractures, pentosidine and homocysteine are independent predictors of incident vertebral fractures under bisphosphonate usage [115]. Therefore, it has been suggested that more investigations into annual changes of bone biomarkers in osteoporotic patients after bisphosphonate treatment may provide clues as to the therapy outcome.

The difference in the baseline fracture risk may also provide a clue in the safety outcome. This has been suggested by Abelson et al who compared the fracture risk in three cohorts of women $(>200,000)$ treated by either alendronate, ibandronate and risedronate [116]. Kim et al have confirmed that prevalent vertebral fractures are strong risk factors for new vertebral fractures among bisphosphonate users [117].

It has been suggested that vitamin D deficiency negatively influence the outcomes of bisphosphonates therapy [118]. However, this finding did not rule out the adverse effects of longterm bisphosphonate therapy in patients with adequate vitamin D levels.

Another issue which should be considered is the individual differences in response to bisphosphonates. Sebba et al reviewed clinical trials and found that BMD does not increase in all patients on bisphosphonate therapy and the rate of 2-year non-responders differs between bisphosphonates [119].

Taken together, the need for more carefully designed investigations in the area of long-term bisphosphonate therapy is obvious. In the future studies, consideration should be given to the baseline BMD, prevalent fractures and risk of fractures in osteoporotic patients, monitoring of bone biomarkers. Furthermore, attention should be paid to the size of the dose and the dosing interval.

In conclusion, until the concerns raised in this review are addressed, prescribers should exercise extra caution in assessing the already known risk factors and consider the risk:benefit ratio of longterm bisphosphonate therapy based on the individual patient's characteristics.

\section{ACKNOWLEDGMENT}

This study was performed as an in-house nonfinancially supported work and authors do not have any conflict of interest.

\section{REFERENCES}

1. Abdollahi M, Larijani B, Rahimi R, Salari P. Role of oxidative stress in osteoporosis. Therapy 2005; 2(5): 787-796.

2. Salari P, Abdollahi M. Controversial effects of non-steroidal anti-inflammatory drugs on bone: a review. Inflamm Allergy Drug Targets 2009; 8(3): 169-175.

3. Salari P, Abdollahi M. A comprehensive review of the shared roles of inflammatory cytokines in osteoporosis and cardiovascular diseases as two common old people problem; action toward 
development of new drugs. Int J Pharmacol. 2011; 7(5): 552-567

4. Salari P, Larijani B, Abdollahi M. Association of hyperhomocysteinemia with osteoporosis: a systematic review. Therapy 2008; 5(2): 215-222.

5. Salari P, Rezaie A, Larijani B, Abdollahi M. A systematic review of the impact of n-3 fatty acids in bone health and osteoporosis. Med Sci Monit. 2008;14(3):RA37-RA44.

6. Salari P, Asalforooush M, Ameri F, Larijani B, Abdollahi M. The effects of $n$-fatty acids on bone biomarkers in Iranian postmenopausal osteoporotic women: a randomized clinical trial. Age 2010; 32:179-186

7. Salari Sharif $P$, Abdollahi M. A systematic review on the relationship between $\beta$-blockers and bone health. Int J Pharmacol. 2010; 6(5):577-583

8. Salari Sharif P, Abdollahi M. The role of platelets in bone remodeling. Inflamm Allergy Drug Target. 2010; 9:393-399

9. Salari Sharif P, Abdollahi M. A systematic review on the relation between use of statins and osteoporosis. Int J Pharmacol. 2011; 7(2):180-188.

10. Salari Sharif P, Abdollahi M, Larijani B. Current new and future treatments of osteoporosis. Rheumatol Int. 2011; 31:289-300

11. Black DM, Thompson DE, Bauer DC, Ensrud K, Musliner T, Hochberg MC, Nevitt MC, Suyawanshi S, Cummings SR; Fracture Intervention Trial. FIT Research Group. Fracture risk reduction with alendronate in women with osteoporosis: the Fracture Intervention Trial. J Clin Endocrinol Metab. 2000; 85:4118-4124.

12. Ensrud KE, Barrett-Connor EL, Schwartz A, Santora AC, Bauer DC, Suryawanshi S, Feldstein A, Haskell WL, Hochberg MC, Torner JC, et al. Randomized trial of effect of alendronate continuation versus discontinuation in women with low BMD: results from the Fracture Intervention Trial long-term extension. J Bone Miner Res. 2004; 19:1259-1269.

13. Papapoulos SE. Use of bisphosphonates in the management of postmenopausal osteoporosis. Ann N Y Acad Sci. 2011; 1218:15-32.

14. Papapoulos SE, Cremers SC. Prolonged bisphosphonate release after treatment in children. N Eng J Med. 2007; 356:1075-1076.

15. Drake MT, Cremers SC. Bisphosphonate therapeutics in bone disease: the hard and soft data on osteoclast inhibition. Mol Interv. 2010; 10(3):141-152.

16. Wysowski DK. Reports of esophageal cancer with oral bisphosphonate use. N Engl J Med. 2009; 360:89-90.

17. Solomon DH PA, Brookhart MA. More on reports of esophageal cancer with oral bisphosphonate use. N Engl J Med. 2009; 360:1789-1790
18. Abrahamsen B, Eiken P, Eastell R. More on reports of esophageal cancer with oral bisphosphonate use. N Engl J Med. 2009;360:1789.

19. Nguyen DM, Schwartz J, Richardson P, El-Serag HB. Oral bisphosphonate prescriptions and risk of esophageal adenocarcinoma in patients with Barretts esophagus. Dig Dis Sci. 2010; 55(12):3404-3407.

20. Green J, Czanner G, Reeves G, Watson J, Wise L, Beral V. Oral bisphosphonates and risk of cancer od esophagus stomach and colorectum: casecontrol analysis within a UK primary care cohort. BMJ 2010; 341:03444.

21. Cardwell CR, Abnet CC, Cantwell MM, Murray LJ. Exposure to oral bisphosphonates and risk of esophageal cancer. JAMA 2010; 304:657-663.

22. Anonymous. Ongoing safety review of oral osteoporosis drugs (bisphosphonates) and potential increased risk of esophageal cancer (2011) FDA. http://www.fda.gov/Drugs/DrugSafety/ucm263320. htm.

23. Khosla S, Burr D, Cauley J, Dempster DW, Ebeling PR, Felsenberg D, Gagel RF, Gilsanz V, Guise T, Koka S, et al. Bisphosphonate associated osteonecrosis of the jaw: report of a task force of the American Society for Bone and Mineral Research. J Bone Miner Res. 2007; 22:1479-1491.

24. Pazianas M. Osteonecrosis of the jaw and the role of macrophages. J Natl Cancer Inst. 2011; 103:232240.

25. Ruggiero SL, Mehrotra B, Rosenberg TJ, Engroff SL. Osteonecrosis of the jaws associated with the use of bisphosphonates: a review of 63 cases. J Oral Maxillofac Surg. 2004; 62(5):527-534.

26. Migliorati CA. Bisphosphonates and oral cavity avascular bone necrosis. J Clin Oncol. 2003; 15:4253-4254.

27. Woo SB, Hellstein JW, Kalmar JR. Narrative review: bisphosphonates and osteonecrosis of the jaws. Ann Intern Med. 2006; 144:753-761.

28. Bamias A, Kastritis E, Bamia C, Moulopoulos LA, Melakopoulos I, Bozas G, Koutsoukou V, Gika D, Anaqnostopoulos A, Papadimitriou C, et al. Osteonecrosis of the jaw in cancer after treatment with bisphosphonates: incidence and risk factors. J Clin Oncol 2005; 23(34): 8580-8587.

29. Edwards BJ, Hellstein JW, Jacobsen PL, Kaltman S, Mariotti A, Migliorati CA, American Dental Association Council on Scientific Affairs Expert Panel on Bisphosphonate-Associated Osteonecrosis of the Jaw. Updated recommendations for managing the care of patients receiving oral bisphosphonate therapy: an advisory statement from the American Dental Association Council on Scientific Affairs. J Am Denta Assoc. 2008; 139(12):1674-1677.

30. Coleman RE, Woodward E, Brown JE, Cameron D, Bell R, Dodwell D, Keane M, Gil M, Davies C, 
Burkinshaw R, et al. Safety of zoledronic acid and incidence of osteonecrosis of the jaw (ONJ) during adjuvant therapy in a randomized phase III trial for women with stage II/III breast cancer. Breast Cancer Res Treat. 2011; 127(2):429-438.

31. Migliorati CA, Epstein JB, Abt E, Berenson JR. Osteonecrosis of the jaw and bisphosphonates in cancer: a narrative review. Nat Rev Endocrinol. 2011; 7:34-42.

32. King AE, Umland EM. Osteonecrosis of the jaw in patients receiving intravenous or oral bisphosphonates. Pharmacotherapy 2008; 28(5): 667-677.

33. Bilezikian JP. Osteonecrosis of the jaw: do bisphosphonates pose a risk? . N Engl J Med. 2006; 355(22):2278-2281

34. Barasch A, Cunha-Cruz J, Curro FA, Hujoel P, Sung AH, Vena D, Voinea-Griffin AE, CONDOR Collaborative Group, Beadnell S, Graig RG, et al. Risk factors for osteonecrosis of the jaws: a casecontrol study from the CONDOR Dental PBRN. J Dent Res. 2011; 9(4):439-444.

35. Black DM, Cummings SR, Karpf DB, Cauley JA, Thompson DE, Nevitt MC, Bauer DC, Genant HK, Haskell WL, Marcus R, et al. Randomised trial of effect of alendronate on risk of fracture in women with existing vertebral fractures. Lancet 1996; 384:1535-1541.

36. Harris ST, Watts NB, Genant HK, McKeever CD, Hangartner T, Keller M, Chesnut $\mathrm{CH} 3^{\text {rd }}$, Brown J, Eriksen EF, Hosevni MS, et al. Effects of risedronate treatment on vertebral and nonvertebral fractures in women with postmenopausal osteoporosis: a randomized controlled trial. JAMA 1999; 282:1344-1352.

37. McClung MR, Geusens P, Miller PD, Zippel H, Bensen WG, Roux C, Adami S, Fogelman I, Diamond T, Eastell R, et al. Effect of risedronate on the risk of hip fracture in elderly women. Hip Intervention Program Study Group. N Engl J Med. 2001; 344:333-340.

38. Black DM, Delmas PD, Eastell R, Reid IR, Boonen S, Cauley JA, Cosman F, Lakatos P, Leung PC, Man Z, et al. Once-yearly zoledronic acid for treatment of postmenopausal osteoporosis. $\mathrm{N}$ Engl J Med. 2007; 356: 1809-1822.

39. Cummings SR, Black DM, Thompson DE, Applegate WB, Barrett-Connor E, Musliner TA, Palermo L, Prineas R, Rubin SM, Scott JC, et al. Effect of alendronate on risk of fracture in women with low bone density but without vertebral fractures: results from the Fracture Intervention Trial. JAMA 1998; 280:2077-2082.

40. Liberman UA, Weiss SR, Broll J, Minne HW, Quan H, Bell NH, Rodriguez-Portales J, Downs RW Jr, Degueker J, Favus M. Effect of oral alendronate on bone mineral density and the incidence of fractures in postmenopausal osteoporosis. The alendronate Phase III Osteoporosis Treatment Study Group. N Engl J Med. 1995; 333:1437-1443.

41. Reginster JY. Risedronate increases bone mineral density and reduces the vertebral fracture incidence in postmenopausal women. Clin Exp Rheumatol. 2001; 19:121-122.

42. Chesnut III CH, Skag A, Christiansen C, Recker R, Stakkestad JA, Hoiseth A, Felsenberg D, Husse H, Gilbride J, Schimmer RC, et al. Effects of oral ibandronate administered daily or intermittently on fracture risk in postmenopausal osteoporosis. J Bone Miner Res. 2004; 1241-1249.

43. McCloskey E, Selby P, Davies M, Robinson J, Francis RM, Adams J, Kayan K, Beneton M, Jalava T, Pylkkänen L, et al. Clodronate reduces vertebral fracture risk in women with postmenopausal or secondary osteoporosis: results of a double-blind placebo-controlled 3-year study. J Bone Miner Res. 2004; 19:728-736.

44. Adachi JD, Rizzoli R, Boonen S, Li Z, Meredith MP, Chesnut $\mathrm{CH} 3^{\text {rd }}$. Vertebral fracture risk reduction with risedronate in post-menopausal women with osteoporosis: a meta-analysis of individual patient data. Aging Clin Exp Res. 2005;17(2):150-156.

45. Roux C, Seeman E, Eastell R, Adachi J, Jackson RD, Felsenberg D, Songcharoen S, Rizzoli R, Di Munno O, Horlait $S$, et al. Efficacy of risedronate on clinical vertebral fractures within six months. Curr Med Res Opin. 2004; 20:433-439.

46. Cranney A, Tugwell P, Adachi J, Weaver B, Zytaruk N, Papaioannou A, Robinson V, Shea B, Wells G, Guyatt G, et al. Meta-analysis of therapies for postmenopausal osteoporosis. III. Meta-analysis of risedronate for the treatment of postmenopausal osteoporosis. Endocr Rev. 2002; 23:517-523.

47. Cranney A, Wells G, William A, Griffith L, Zytaruk N, Robinson V, Black D, Adachi J, Shea $\mathrm{B}$, Tugwell $\mathrm{P}$, et al. Meta-analysis of therapies for postmenopausal osteoporosis. II. Meta-analysis of alendronate for the treatment of postmenopausal women. Endocr Rev. 2002; 23:508-516.

48. Karpf DB SD, Seeman E, Ensrud KE, Johnston CC, Adami S, Harris ST, Santora AC $2^{\text {nd }}$, Hirsch LJ, Oppenheimer L, et al. Prevention of nonvertebral fractures by alendronate. A metaanalysis. Alendronate Osteoporosis Treament Study Groups. JAMA 1997; 277:1159-1164.

49. Papapoulos SE, Quandt SA, Liberman UA, Hochberg MC, Thompson DE. Meta-analysis of the efficacy of alendronate for the prevention of hip fractures in postmenopausal women. Osteoporosis Int. 2005; 16:468-474.

50. Boonen S, Laan RF, Barton IP, Watts NB. Effect of osteoporosis treatments on risk of non-vertebral fractures: review and meta-analysis of intention-totreat studies. Osteoporosis Int. 2005; 16:1291-1298. 
51. Nguyen ND, Eisman JA, Nguyen TV. Anti-hip fracture efficacy of biophosphonates: a Bayesian analysis of clinical trials. J Bone Miner Res. 2006; 21:340-349.

52. Wells GA, Cranney A, Peterson J, Boucher M, Shea B, Robinson V, Coyle D, Tugwell P. Alendronate for the primary and secondary prevention of osteoporotic fractures in postmenopausal women. Cochrane Database Syst Rev. 2008; 1:CD001155.

53. Pols HA, Felsenberg D, Hanley DA, Stepan J, Muňoz-Torres M, Wilkin TJ, Qin-Sheng G, Galich AM, Vandormael K, Yates AJ, et al. Multinational placebo-controlled randomized trial of the effects of alendronate on bone density and fracture risk in postmenopausal women with low bone mass: results of the FOSIT Study. Osteoporos Int. 1999; 9:461-468.

54. Wells GA, Cranney A, Peterson J, Boucher M, Shea B, Robinson V, Coyle D, Tugwell P. Risedronate for the primary and secondary prevention of osteoporotic fractures in postmenopausal women. Cochrane Database Syst Rev. 2008; 1:CD004523

55. Wells GA, Cranney A, Peterson J, Boucher M, Shea B, Robinson V, Coyle D, Tugwell P. Etidronate for the primary and secondary prevention of osteoporotic fractures in postmenopausal women. Cochrane Database Syst Rev. 2008; 1:CD003376

56. Harrington JT, Ste-Marie LG, Brandi ML, Civitelli R, Fardellone P, Grauer A, Barton I, Boonen S. Risedronate rapidly reduces the risk for nonvertebral fractures in women with postmenopausal osteoporosis. Calcif Tissue Int. 2004; 74:129-135.

57. Watts NB, Diab DL. Long-term use of bisphosphonates in osteoporosis. J Clin Endocrinol Metab. 2010; 95:1555-1565.

58. Shane E. Evolving data about subtrochanteric fractures and bisphosphonates. $\mathrm{N}$ Engl $\mathrm{J}$ Med. 2010; 362:1825-1827.

59. Abrahamsen B, Eiken P, Eastell R. Subtrochanteric and diaphyseal femur fractures in patients treated with alendronate: a register-based national cohort study. J Bone Miner Res. 2009; 24:1095-1102.

60. Black DM, Kelly MP, Genant HK, Palermo L, Eastell R, Bucci-Rechtweg C, Cauley J, Leung PC, Boonen S, Santora A, et al. Bisphosphonates and fractures of the subtrochanteric or diaphyseal femur. N Engl J Med. 2010; 362:1761-1771.

61. Odvina CV, Zerwekh JE, Rao DE, Maalouf N, Gottschalk FA, Pak CY. Severely suppressed bone turnover: a potential complication of alendronate therapy. J Clin Endocrinol Metab. 2005;90:12941301.

62. Bone HG, Hosking D, Devogelaer JP, Tucci JR, Emkey RD, Tonino RP, Rodriguez-Portales JA,
Downs RW, Gupta J, Santora AC, et al. Ten years experience with alendronate for osteoporosis in postmenopausal women. N Eng J Med. 2004; 350:1189-1199.

63. Charopoulos I, Orme S, Giannoudis PV. Fracture risk associated with chronic use of bisphosphonates: evidence today. Expert Opin Drug Saf. 2011; 10 (1):67-76.

64. Goh SK, Yang KY, Koh JS, Wong MK, Chua SY, Chua DT, Howe TS. Subtrochanteric insufficiency fractures in patients on alendronate therapy: a caution. J Bone Joint Surg Br. 2007; 89:349-353.

65. Kwek EB, Goh SK, Koh JS, png MA, Howe TS. An emerging pattern of subtrochanteric stress fractures: a long term complication of alendronate therapy? Injury. 2008; 39:224-231.

66. Neviaser AS, Lane JM, Lenart BA, Edobor-Osula F, Lorich DG. Low-energy femoral shaft fractures associated with alendronate use. J Orthop Trauma. 2008; 22:346-350.

67. Lenart BA, Lorich DG, Lane JM. Atypical fractures of the femoral diaphysis in postmenopausal women taking alendronate. N Eng J Med. 2008; 358:1304-1306.

68. Visekruna M, Wilson D, McKiernan FE. Severely suppressed bone turnover and atypical skeletal fragility. J Clin Endocrinol Metab. 2008; 93:29482952.

69. Venkatanarasimha N, Miles G, Suresh P. Subtrochanteric femoral insufficiency fractures related to the use of long-term bisphosphonates: a pictorial review. Emerg Radiol. 2010; 17:511-515.

70. Lee JK. Bilateral atypical femoral diaphyseal fratctures in a patient treated with alendronate sodium. Int J Rheum Dis. 2009; 12:149-154.

71. Kim SY, Schneeweiss S, Katz JN, Levin R, Solomon DH. Oral bisphosphonates and risk of subtrochanteric or diaphyseal femur fractures in a population-based cohort. J Bone Miner Res. 2011; 26(5):993-1001.

72. Park-Wyllie LY, Mamdani MM, Juurlink DN, Hawker GA, Gunrai N, Austin PC, Whelan DB, Weiler PJ, Laupacis A. Bisphosphonate use and the risk of subtrochanteric or femoral shaft fractures in older women. JAMA 2011; 305 (8):783-789.

73. Ing-Lorenzini K, Desmeules J, Plachta O, Suva D, Dayer P, Peter R. Low-energy femoral fractures associated with the long-term use of bisphosphonates: a case series from a Swiss university hospital. Drug Saf. 2009; 32:775-785.

74. Capeci CM, Tejwani NC. Bilateral low-energy simultaneous or sequential femoral fractures in patients on long-tem alendronate therapy. J Bone Joint Surg Am. 2009; 91:2556-2561.

75. Odvina CV, Levy S, Rao S, Zerwekh JE, Rao DS. Unusual mid-shaft fractures during long-term bisphosphonate therapy. Clin Endocrinol (Oxf). 2010; 72:161-168. 
76. Lenart BA, Neviaser AS, Lyman S, Chang CC, Edobor-Osula F, Steele B, van der Meulen MC, Lorich DG, Lane JM. Association of low-energy femoral fractures with prolonged bisphosphonate use: a case control study. Osteoporos Int. 2009; 20:1353-1362.

77. Isaacs JD, Shidiak L, Harris IA, Szomor ZL. Femoral insufficiency fractures associated with prolonged bisphosphonate therapy. Clin Orthop Relat Res. 2010; 468(12):3384-3392.

78. Girgis CM, Sher D, Siebel MJ. Atypical femoral fractures and bisphosphonate use. N Engl J Med. 2010; 362:1848-1849.

79. Schilcher J, Aspenberg P. Incidence of stress fractures of femoral shaft in women treated with bisphosphonate. Acta Orthop. 2009; 80:413-415.

80. Stepan JJ, Burr DB, Pavo I, Sipos A, Michalska D, Li J, Fahrleitner-Pammer A, Petto H, Westmore M, Michalsky D, et al. Low bone mineral density is associated with bone microdamage accumulation in postmenopausal women with osteoporosis. Bone 2007; 41:378-385.

81. Chapurlat RD, Arlot M, Burt-Pichat B, Chavassieux P, Roux JP, Portero-Muzy N, delmas PD. Microcrack frequency and bone remodeling in postmenopausal osteoporotis women on long-term bisphosphonates: a bone biopsy study. J Bone Miner Res. 2007; 22:1502-1509.

82. Rizzoli R, Akesson K, Bouxsein M, Kanis JA, Napoli N, Papapoulos S, Reginster JY, Cooper C. Subtrochanteric fractures after long-term treatment with bisphosphonates: a European Society on Clinical and Economic Aspects of Osteoporosis and Osteoarthritis, and International Osteoporosis Foundation Working Group Report. Osteoporos Int. 2011; 22:373-390.

83. Coló-Emeric CS, Lyles KW, Su G, Pieper CF, Magaziner JS, Adachi JD, Bucci-Rechtweg CM, Haentiens P, Boonen S, HORIZON Recurrent Fracture Trial. Clinical risk factors for recurrent fracture after hip fracture: a prospective study. Calcif Tissue Int. 2011; 88:425-431.

84. Felsenberg D, Miller P, Armbrecht G, Wilson K, Schimmer RC, Papapoulos SE. Oral ibandronate significantly reduces the risk of vertebral fractures of greater severity after 1,2 , and 3 years in postmenopausal women with osteoporosis. Bone 2005; 37:651-654.

85. Mellström DD, Sörensen OH, Goemaere S, Roux C, Johnson TD, Chines AA. Seven years of treatment with risedronate in women with postmenopausal osteoporosis. Calcif Tissue Int. 2004; 75:462-468.

86. Black DM, Schwartz AV, Ensrud KE, Cauley JA, Levis S, Quandt SA, Satterfield S, Wallace RB, Nauer DC, Palermo L, et al. Effects of continuing or stopping alendronate after 5 years of treatment. JAMA 2006; 296 (24):2927-2938.
87. Schwartz AV, Bauer DC, Cummings SR, Cauley JA, Ensrud KE, Palermo L, Wallace RB, Hochberg MC, Feldstein AC, Lombardi A, et al. Efficacy of continued alendronate for fractures in women with and without prevalent vertebral fracture: the FLEX Trial. J Bone Miner Res. 2010; 25 (5):976-982.

88. Makras P, Hamdy NA, Zwinderman AH, Ballieux BEPB, Papapoulos SE. Bisphosphonate dose and incidence of fractures in postmenopausal osteoporosis. Bone 2009; 44:766-771.

89. Cummings SR, Schwartz AV, Black DM. Alendronate and atrial fibrillation. N Engl J Med. 2007; 356:1895-1896.

90. Karam R, Camm J, McClung M. Yearly zoledronic acid in postmenopausal osteoporosis. $\mathrm{N}$ Engl $\mathrm{J}$ Med. 2007; 357:712-713.

91. Anonymous. Early communication of an ongoing safety review. Bisphosphonates: alendronate (Fosamax, Fosamax Plus D), etidronate (Didronel), ibandronate (Boniva), pamidronate (Aredia), risedronate (Actonel, Actonel w/calcium), tiludronate (Skelid), and zoledronic acid (Reclast, Zometa).Availableat:http://www.fda.gov/Cder/Dru g/early_comm/bisphosphonates.htm.

Accessed March 13, 2008.

92. Heckbert SR, Li G, Cummings SR, Smith NL, Psaty BM. Use of elandronate and risk of incident atrial fibrillation in women. Arch Intern Med. 2008; 168:826-831.

93. Abrahamsen B, Eiken P, Brixen K. Atrial fibrillation in fracture patients treated with an oral bisphosphonate. J Intern Med. 2009; 265:581-592.

94. Bunch TJ, Anderson JL, May HT, Nuhlestein JB, Horne BD, Crandall BG, Weiss JP, Lappé DL, Osborn JS, Day JD. Relation of bisphosphonate therapies and risks of developing atrial fibrillation. Am J Cardiol. 2009; 103:824-828.

95. Vestergaard P, Schwartz K, Pinholt F, Rejnmark L, Mosekilde L. Risk of atrial fibrillation associated with use of bisphosphonates and other drugs against osteoporosis: a cohort study. Calcif Tissue Int. 2010; 86:335-342.

96. Huang W, Tsai Y, Wen Y, Hsiao FY, Kuo KN, Tsai CR. Osteoporosis treatment and atrial fibrillation: alendronate versus raloxifene. Menopause. 2010; 17:57-63.

97. Sorensen HT, Christensen S, Mehnert F, Pedersen L, Chapurlat RD, Cummings SR, Baron JA. Use of bisphosphonates among women and risk of atrial fibrillation and flutter: population based case control study. BMJ. 2008; 336:813-816.

98. Grosso A, Douglas I, Hingorani A, MacAllister R, Smeeth L. Oral bisphosphonates and risk of atrial fibrillation and flutter in women: a self-controlled case-series safety analysis. PLoS ONE. 2009; 4(3):e4720.

99. Loke YK, Jeevanantham V, Singh S. Bisphosphonates and atrial fibrillation: systematic 
review and meta-analysis. Drug Saf. 2009; 32:219228.

100. Kim SY, Kim MJ, Cadarette SM, Solomon DH. Bisphosphonates and risk of atrial fibrillation: a meta-analysis. Arthritis Res Ther. 2010; 12(1):R30.

101. Mak A, Cheung MW, Ho RC, Cheak AA, Lau CS. Bisphosphonates and atrial fibrillation: Bayesian meta-analysis of randomized controlled trials and observational studies. BMC Musculoskeletal Disrders. 2009; 10:113.

102. Bhuriya R, Singh M, Molnar J, Arora R, Khosla S. Bisphosphonate use in women and the risk of atrial fibrillation: a systematic review and meta-analysis. Int J Cardiol. 2010; 142 (3):213-217.

103. Pazanias M, Compston J, Huang CL. Atrial fibrillation and bisphosphonate therapy. J Bone Miner Res. 2010; 25:2-10.

104. John Camm A. Review of the cardiovascular safety of zoledronic acid and other bisphosphonates for the treatment of osteoporosis. Clin Ther. 2010; 32:426-436.

105. Lyles KW, Colón-Emeric CS, Magaziner JS, Adachi JD, Pieper CF, Mautalen C, Hyldstrup L, Recknor C, Nordsletten L, Moore KA, et al. For the HORIZON Recurrent Fracture Trial. Zoledronic acid in reducing clinical fracture and mortality after hip fracture. N Engl J Med. 2007; 357:1799-1809.

106. Boivin G, Farlay D, Bala y, Doublier A, Meunier PJ, Delmas PD. Influence of remodeling on the mineralization of bone tissue. Osteoporos Int. 2009; 20:1023-1026.

107. Allen MR, Reinwald S, Burr DB. Alendronate reduces bone toughness of ribs without significantly increasing microdamage accumulation in dogs following 3 years of daily treatment. Calcif Tissue Int. 2008; 82:354-360.

108. Recker RR, Delmas PD, Halse J, Reid IR, Boonen S, Garcia-Hernandez PA, Supronik J, Lewiecki EM, Ochoa L, Miller $P$, et al. Effects of intravenous zoledronic acid once yearly on bone remodeling and bone structure. J Bone Miner Res. 2008; 23:2-5.

109. Recker RR, Weinstein RS, Chesnut CH III, Schimmer RC, Mahoney P, Hughes C, Bonvoisin B, Meunier PJ. Histomorphometric evaluation of daily and intermittent oral ibandronate in women with postmenopausal osteoporosis: results from the BONE study. Osteoporos Int. 2004; 15:231-237.

110. Allen MR, Iwata K, Phipps R, Burr DB. Alterations in canine vertebral bone turnover microdamage accumulation and biochemical properties following 1-year treatment with clinical treatment doses of risedronate or alendronate. Bone 2006; 39:872-879.

111. Mashiba T, Hui S, Turner CH, Mori S, Johnston CC, Burr DB. Bone remodeling at the iliac crest can predict the changes in remodeling dynamics microdamage accumulation and mechanical properties in the lumbar vertebrae of dogs. Calcif Tissue Int. 2005; 77:180-185.

112. Shiraki M, Yamazaki Y, Shiraki Y, Hosoi T, Tsugawa N, Okano T. High level of serum undercarboxylated osteocalcin in patients with incident fractures during bisphosphonate treatment. J Bone Miner Metab. 2010; 28:578-584.

113. Armamento-Villareal R, Napoli N, Diemer K, et al. Bone turnover in bone biopsies of patients with low-energy cortical fractures receiving bisphosphonates; a case series. Calcif Tissue Int. 2009; 85:37-44.

114. Iba K, Takada J, Sasaki K, Wada T, Yamashita T. Course of NTX changes under continuous bisphosphonate treatment in cases of NTX overreductio due to long-term treatment with bisphosphonates. J Orthop Sci. 2011; 16:71-76.

115. Shiraki M, Kuroda T, Shiraki Y, Tanaka S, Higuchi T, Saito M. Urinary pentosidine and plasma homocysteine levels at baseline predict future fractures in osteoporosis patients under bisphosphonate treatment. J Bone Miner Metab. 2011; 29:62-70.

116. Abelson A, Ringe JD, Gold DT, Lange JL, Thomas $\mathrm{T}$. Longitudinal change in clinical fracture incidence after initiation of bisphosphonates. Osteoporos Int. 2010; 21:1021-1029.

117. Kim SH, Choi HS, Rhee Y, Kim KJ, Lim SK. Prevalent vertebral fractures predict subsequent radiographic vertebral fractures in postmenopausal Korean women receiving antiresorptive agent. Osteoporos Int. 2011; 22:781-787.

118. Adami S, Giannini S, Bianchi G, Sinigaglia L, Di Munno O, Flore CE, Minisola S, Rossini M. Vitamin D status and response to treatment in postmenopausal osteoporosis. Osteoporos Int. 2009; 20(2):239-244.

119. Sebba AI. Significance of a decline in bone mineral density while receiving oral bisphosphonate treatment. Clin Ther. 2008; 39(3):443-452.

120. Occhicone F, Quattrocchi CC, Napoli N, DellÁia P, DÁgostino F, Pozzilli P, Beomonte Zobel B. Incidence of new fractures in women with osteoporotic-induced vertebral fractures detected on routine lateral chest radiographs. Radiol Med. 2010; 115:815-825.

121. Hwang JS, Chin LS, Chen JF, Yang TS, Chen PQ, Tsai KS, Leung PC. The effects of intravenous zoledronic acid in Chinese women with postmenopausal osteoporosis. J Bone Miner Metab. $2011 ; 29: 328-333$. 